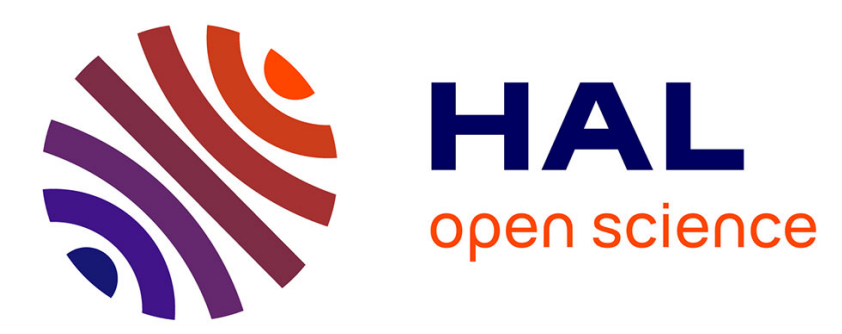

\title{
ELECTROREFLECTANCE AND SPECTROSCOPIC ELLIPSOMETRY STUDIES OF GaAs/GaAlAs HETEROJUNCTIONS
}

\author{
C. Alibert, Sophie Gaillard, M. Erman, P. Frijlink
}

\section{- To cite this version:}

C. Alibert, Sophie Gaillard, M. Erman, P. Frijlink. ELECTROREFLECTANCE AND SPECTROSCOPIC ELLIPSOMETRY STUDIES OF GaAs/GaAlAs HETEROJUNCTIONS. Journal de Physique Colloques, 1983, 44 (C10), pp.C10-229-C10-233. 10.1051/jphyscol:19831048 . jpa00223505

\section{HAL Id: jpa-00223505 https://hal.science/jpa-00223505}

Submitted on 1 Jan 1983

HAL is a multi-disciplinary open access archive for the deposit and dissemination of scientific research documents, whether they are published or not. The documents may come from teaching and research institutions in France or abroad, or from public or private research centers.
L'archive ouverte pluridisciplinaire HAL, est destinée au dépôt et à la diffusion de documents scientifiques de niveau recherche, publiés ou non, émanant des établissements d'enseignement et de recherche français ou étrangers, des laboratoires publics ou privés. 


\title{
ELECTROREFLECTANCE AND SPECTROSCOPIC ELLIPSOMETRY STUDIES OF GaAs/GaAIAS HETEROJUNCTIONS
}

\author{
C. Alibert, S. Gaillard, M. Erman ${ }^{*}$ and P.M. Frijlink \\ Université des Sciences et Techniques du Languedoc, Place Eugène Batailion, \\ 34060 Montpelzier, France \\ * Laboratoires d'Electronique et de Physique Appliquée, 3, Avenue Descartes, \\ 94450 Limeiz Brévannes, France
}

Résumé - Des hétérostructures GaAlAs/GaAs obtenues par croissance en phase vapeur aux organométalliques sont analysés par électroréflexion dans la région $\mathrm{E}_{0}, \mathrm{~F}_{0}+\Delta_{0}$ des deux matériaux. Les résultats sont comparés avec ceux obtenus en ellipsométrie spectroscopique dans la gamme 1.6 à $5.4 \mathrm{eV}$. Les structures des spectres d'électroréflexion des couches minces (en dessous de $100 \AA$ A) sont très bien résolues même à température ambiante. Les structures "normales" (couche mince de GaAs sur une couche épaisse de GaAlAs) et "inversées" (couche mince de GaAlAs sur couche épaisse de GaAs) sont étudiées par les deux techniques. On obtient ainsi des informations concernant la composition, les régions d'interface et la qualité des couches. Les avantages et les limitations propres aux deux méthodes sont discutés.

Abstract - M.0.V.P.E. grown GaAlAs/GaAs heterojunctions have been examined by modulation spectroscopy (electro reflectance $-E R$ ) in the $E_{0}, E_{0}+\Delta_{0}$ region of both materials and compared with spectroscopic ellipsometry (S.E.) analysis in the $1.6-5.4 \mathrm{eV}$ region. The electro-reflectance structures of thin layer (below $100 \AA$ ) of GaAlAs and GaAs are well resolved, even at room temperature. The "normal" (thin GaAlAs layer on top of GaAs substrate) and "inverted" (thin GaAs layer on top of GaAlAs thick film) heterostructures are analyzed using both techniques. Informations about composition, interface region and layer quality are obtained. The respective advantages and limitations of the two techniques are discussed.

Introduction - The analysis of heterojunctions in III-V semiconductor material is of great practical importance because of the recently introduced novel devices such as solid state lasers with low threshold current or high electron mobility transistors. Crystallographic informations are needed i.e. what is the atomic arrangement in the vicinity of a transition between GaAs and GaAlAs layers. This can be obtained in a non destructive way by spectroscopic ellipsometry (S.E.) since the evaluation of the dielectric function of the material as a function of depth is in fact a chemical analysis (1). Non destructive analysis of the electronic states at the interfaces or in the thin layers of a multilayer stack is also possible using a combination of electrical and optical methods namely electroreflectance ( $E$ ). We will illustrate here the use of both techniques (SE and ER) on state of the art heterojunctions fabricated by metallorganic vapour phase epitaxy (MO-VPE).

\section{Experimental}

Three samples have been examined which were grown by MOVPE at $650{ }^{\circ} \mathrm{C}$ at a growth rate of $5 \mathrm{~A} / \mathrm{sec}$. Two lines of gas flows were adjusted for pure GaAs and GaAlAs (54\% Al) respectively. The hydrodynamic conditions in the VPE reactor was arranged in such a way that gas composition over the wafer could be changed within 0.1 sec. (2). In the sample 1 i.e. "inverted" structure (respectively 2 i.e. "normal" structure) the best possible interface of a GaAs layer over a GaAlAs thick film (respectively GaAlAs over GaAs) has been grown with the additional constraint that the interface has to be located at $\sim 100 \AA$ from the surface in order to be 
reached by the light in the whole visible-near U.V. range. For the sample 3 , a non abrupt interface has been simulated by growing a sequence of 10

( $(1.5 \AA \mathrm{AaAs}+1.5 \AA \mathrm{GaAlAs})$ layers. This should give a $\sim 30 \AA$ of a mixture of the $0 \%$ and $54 \%$ material i.e. the equivalent of a (27 $\% \mathrm{Al}$ ) GaAlAs layer.
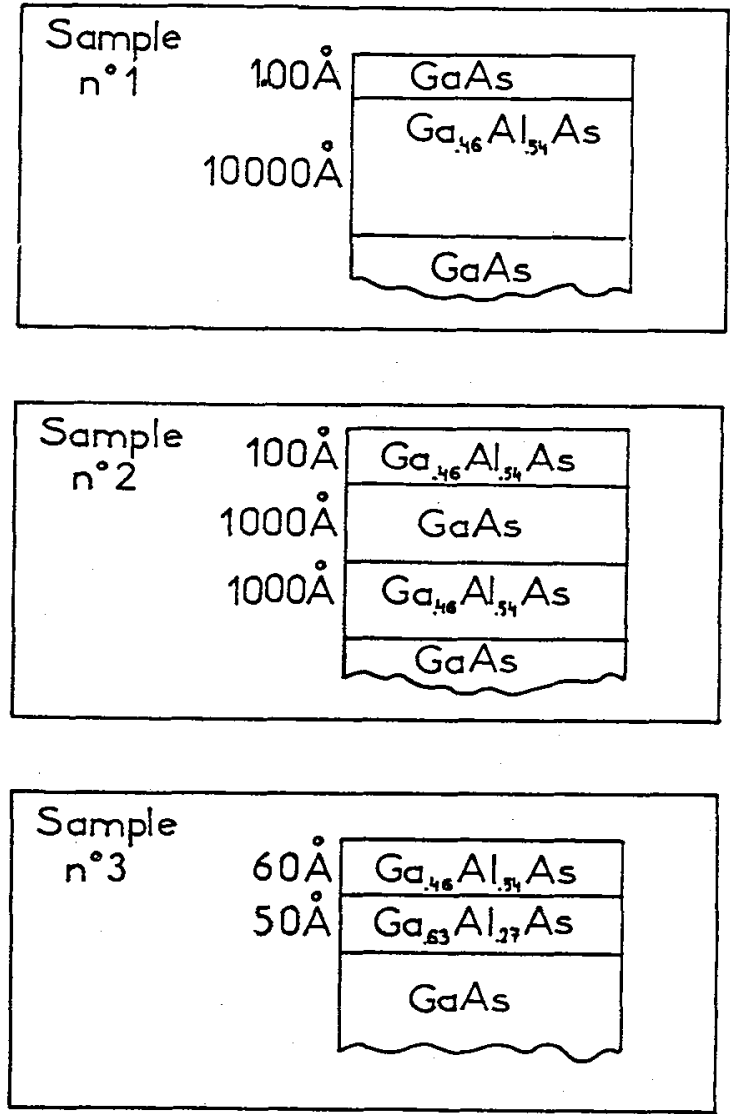

Fig. 1 - Summarizes the characteristics expected for the three structures

The spectroscopic ellipsometer operates in ambiant air. It is of the rotating polarizer type and covers the $1.6-5.4 \mathrm{eV}$ range (3). The electroreflectance was measured after deposition of a $\mathrm{Cu}_{2} \mathrm{~S}$ film used as a biasing electrode. The experimental system has been described elsewhere (4).

Analysis of the inverted structure (Sample $n^{\circ} 1$ ). ER Spectrum : The structures between 1.3 and $2 \mathrm{eV}$ are due to the $E_{0}$ transition in the $60 \AA$ GaAs top layer together with the Franz-Keldysh oscillations (FKO). The $E_{0}+\Delta_{0}$ structure is masqued by the $E_{0}$ FKO.According to (5), the electric field corresponding to such a spectrum is in the strong field limit. The field is due to electronic states at the surface of the GaAs top layer. There is an odd structure at $1.4 \mathrm{eV}$ probably due to impurities. Both facts indicate that this GaAs layer is of poor electrical quality. The $E_{0}$ transition associated with GaAlAs 
is in fact a doublet, with a $80 \mathrm{meV}$ separation. This is probably due to stresses in the GaAlAs, as already observed by F.H. Pollak et al (6).

SE analysis : The oscillations in the $1.6-2.2 \mathrm{eV}$ region are due to interferences in the GaAlAs layer and can be used to evaluate the thickness of this layer. Near $3 \mathrm{eV}, \tan \psi$ exhibits a double structure due to the presence of the GaAs overlayer. By multilayer analysis and linear regression an interface region $(\sim 15 \AA)$ is detected. The parameters of the model deduced from the linear regression analysis are given in the inset of Fig. $2 \mathrm{~b}$.

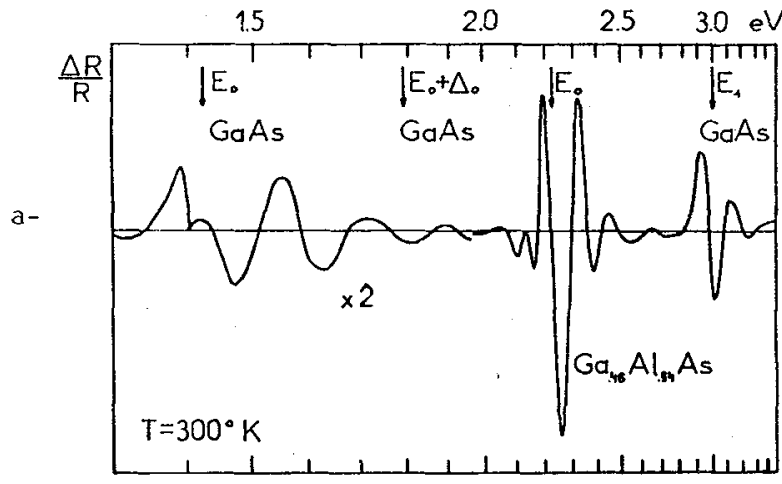

Fig. 2 - ER spectrum of the inverted structure

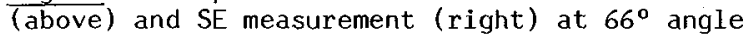
of incidence. Experimental curve (full line) is compared to a 3 layer model (dotted line).

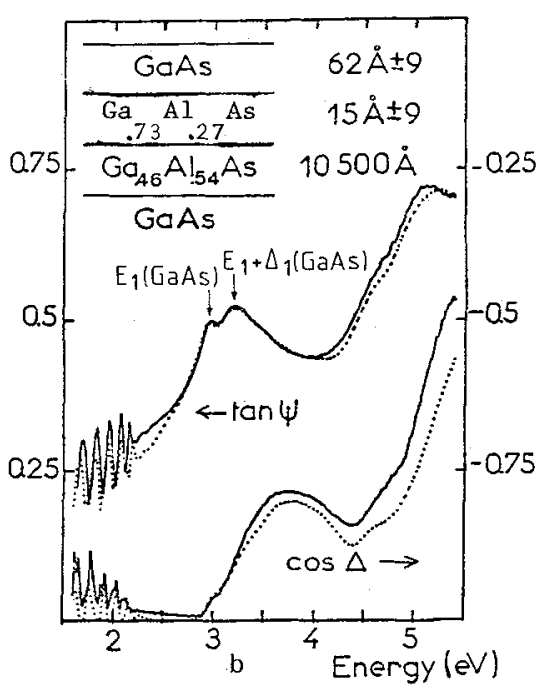

Analysis of the normal structure (Sample $n^{\circ}$ 2)

SE analysis: The oscillations in the $1.6-2.5$ ev region are again due to the interferences in the buffer layer (1000 $\AA \mathrm{GaAs}$ and $1000 \AA \mathrm{GaAlAs}$ ). In the $3-4 \mathrm{eV}$ region $E_{1}$ and $E_{1}+\Delta_{1}$ structures of GaAs and GaAlAs are clearly seen. This region is particularly sensitive to the presence of an interface region. From the SE data, using multilayer analysis, this interface is found to be smaller than one monolayer. One has to conclude that the GaAlAs/GaAs heterojunction is issentially abrupt from the viewpoint of its optical response. It is definitely better defined than the "inverted" structure.

ER Spectrum : The $E_{0}, E_{0}+\Delta_{0}$ structures of GaAs and GaAlAs $(A l=54 \%)$ layers are well resolved, namely:

$$
\begin{aligned}
& \text { GaAs } \quad\left(\begin{array}{ll}
E_{0} & 1.420 \pm 0.003 \mathrm{eV} \\
E_{0}+\Delta_{0} & 1.760 \pm 0.003 \mathrm{eV}
\end{array}\right. \\
& \text { GaAlAs } \quad\left(\begin{array}{ll}
E_{0} & 2.210 \mathrm{eV} \\
E_{0}+\Delta_{0} & 2.535 \mathrm{eV}
\end{array}\right.
\end{aligned}
$$

These values are obtained using the three point method (7).

One can notice that there is only one line for two GaAlAs layers, indicating that the composition is very uniform.

There is an extra peak at $1.49 \mathrm{eV}$. By varying the bias, one can demonstrate that this is not an FKO. This structure might be due to localized levels at the GaAlAs/GaAs heterojunction (triangular well induced by the electric field applied to the sample). In fact, at $1.49 \mathrm{eV}$, the light penetrates down to the GaAs substrate. Several heterojunctions (as seen in Fig. 3) could contribute to this peak. 

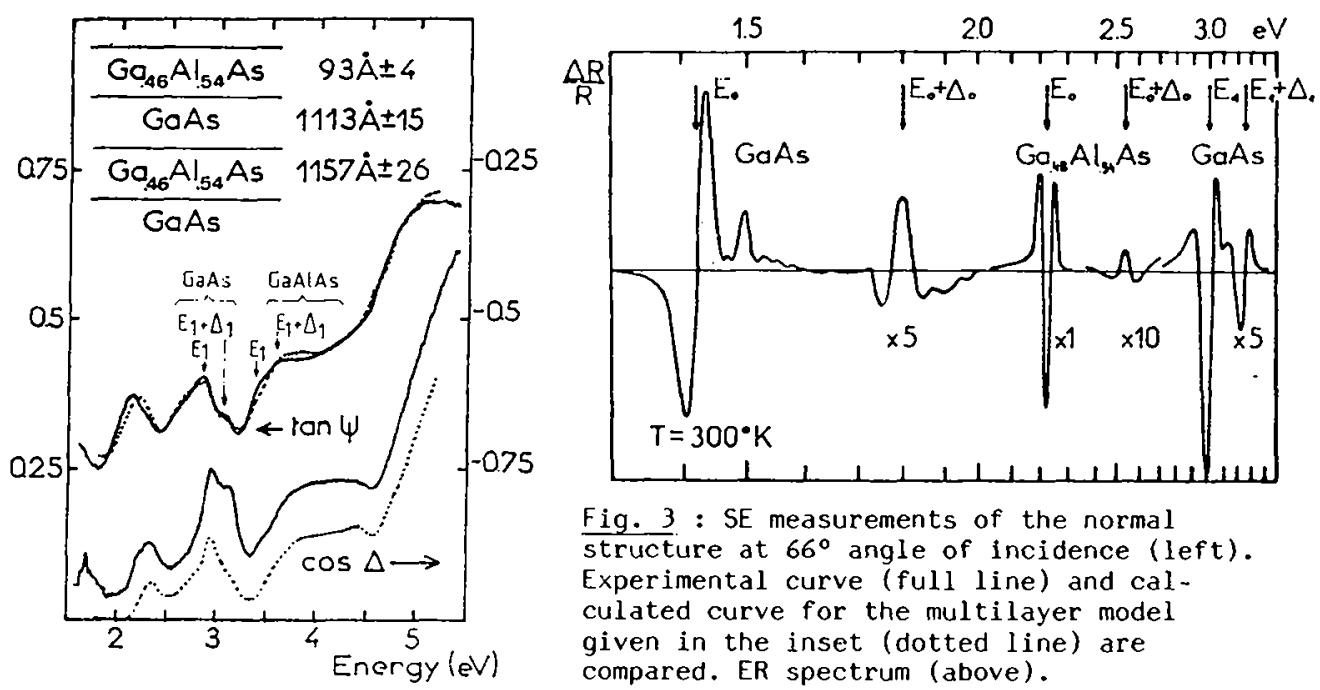

Fig. 3 : SE measurements of the normal structure at $66^{\circ}$ angle of incidence (left). Experimental curve (full line) and calculated curve for the multilayer model given in the inset (dotted line) are compared. ER spectrum (above).

Analysis of the graded heterojunction (Sample $n^{\circ} 3$ )

ER spectrum : Apart from the expected $E_{0}$ and $E_{0}+\Delta_{0}$ structure from the GaAs substrate, two weak peaks are detected at $1.67 \mathrm{eV}$ and $1.97 \mathrm{eV}$. This corresponds to $E_{0}$ transition in GaAlAs layers with $18 \%$ and $36 \% \mathrm{Al}$ respectively. The relative values for the compositions are in good agreement with the expected ones from the growth parameters. Furthermore, this demonstrates that a layer as thin as $30 \AA$ can be detected and that a $60 \AA$ thick GaAlAs layer can have a well defined and narrow $E_{0}$ structure.

SE analysis : To analyse the interface region two models have been used : one assuming a physical interface ( $\sim 50 \%$ GaAs and $\left.50 \% \mathrm{Ga} .46^{\mathrm{Al}} .54^{\mathrm{As}} \mathrm{mixture}\right)$, the other a chemical interface (a layer of GaAlAs with intermediate Al composition). The fit is markedly better with a chemical mixture interface $30 \AA$ thick.

The compositions ( $27 \%$ and $54 \%$ of $A 1)$ differ slighty from those found by ER. In fact, in our SE analysis, we have not varied those compositions, assuming they were the same as deduced from the growth conditions. Generally speaking SE is less sensitive than ER to the composition, while it is best suited for evaluating the thicknesses.

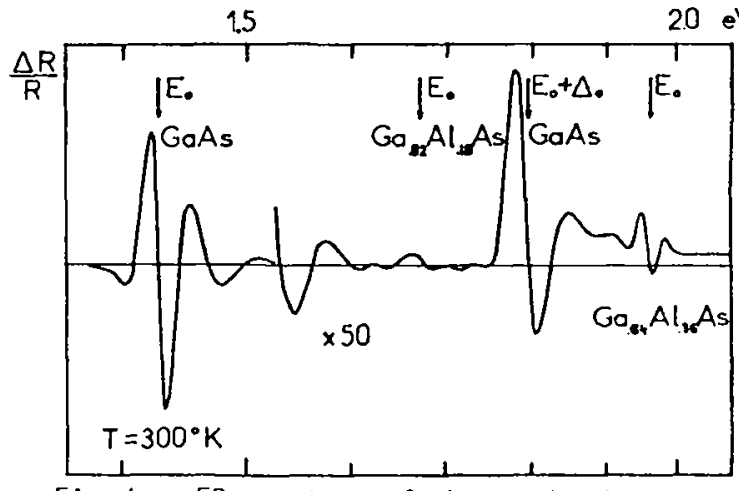

Fig. 4 - ER spectrum of the grades heterojunction (above) and SE measurement at $66^{\circ}$ angle of incidence (right). Experimental curve (full line) and calculated curve for the inset multilayer structure (dotted line) are compared.

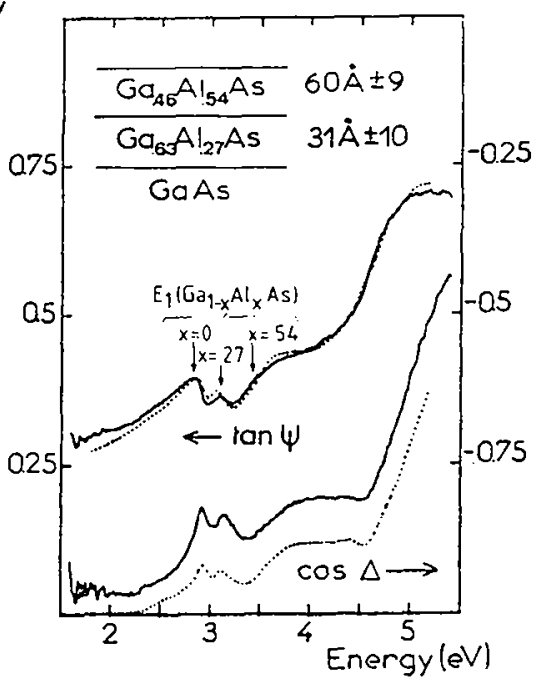




\section{References}

1 - ERMAN M., THEETEN J.B., VODJDANI N., DEMAY Y., Proceeding of the Int. Conf. on Metastable and modulated Semiconductor Structures, Pasadena, California (Dec. 1982).

2 - FRIJLINK P., MALUENDA J., Japanese J. Appl. Phys. 21 (1982) L 574.

3 - THEETEN J.B., SIMONDET F., ERMAN M. and PERNAS J., Proceedings of the $4^{\text {th }}$ Intern. Conf. on Solid Surfaces, (Cannes, France, Sept. 1980), Le Vide (Les Couches Minces) 201 (1980) 107I.

4 - Alibert c., Bordure G., Laugier A., Chevallier J., Phys. Rev. B6 (1972) 1301.

5 - ASPNES D.E., Phys. Rev. BlO (1974) 4228.

6 - POLLAK F.H. and WOODALL J.M., J. Vac. Sci. Technol. 17 (1980) 1108.

7 - ASPNES D.E. and ROWE J.E., Phys. Rev. Letters, 27 (1971) 188.

This work is supported by the D.G.R.S.T. 